\title{
CONFERENCE OF LADIES ON DOMESTIC HYGIENE.
}

\section{ADDRESS}

\section{BY THE LADY MAYORESS OF LIVERPOOL}

(MRS. W. B. BOWRING).

PRESIDENT OF THE CONFERENCE.

In opening this Conference on Domestic Hygiene, it is neither necessary, nor would it be fitting, that I should occupy your time with an address of any length-seeing that we are to listen to-day to papers read by those whose wille experience and depth of knowledge render them far abler exponents of the theories they wish to promulgate than I could possibly be. I will, therefore, confine myself merely to a few general remarks upon the subject which we are assembled here to discuss, and the reasons why it is well that we, as women, should in this Sanitary Congress have a recognised position to maintain and an organized gathering of our own. It has been truly said: "Architects may build houses which in point of structure shall be very temples of Hygeia, but woman will ever make them nurseries of disease and death so long as she ignorantly violates household sanitary law;" and yet in spite of the accuracy of such a statement how little is done, or rather how much more is needed to be done, in order to train girls to a right estimate of the value of those sanitary laws, and to give them an opportunity to acquire that intelligent knowledge of hygiene and sanitation which is so absolutely essential to the physical and moral welfare of both indiviluals and communities. In these days of alvanced thought we hear much of "the rights of women" and "the revolt of the daughters," movements that have for their aim the increased freedom of the sex, but still, when all is said, the household - the home, remains woman's true kinglom, it is there her sway is paramount, it is there her influence is supreme; its interests should be her first consideration, its maintenance and improvement lie nearest to her heart. How best to inculcate the desire for this improvement amongst our less fortunate sisters; how most wisely and sympathetically 
to impart such teaching as will conduce to a higher standard for their health and for their homes, should be, it seems to me, the key-note of our conference to-day.

There never was a time when sanitation, or to put it more plainly "health in the house," was so much discussed, so talked of, so written alout as at the present time, one might almost say that it has become a fashionable craze and that in the flood of sanitary books, pamphlets, publications and lectures poured upon us there is some fear of our being swept away by a deluge of theories beyond our grasp, instead of standing firmly on the solid ground of practical common-sense; and olld-fashioned people are apt to shake their heads and quote "when ignorance is bliss 'tis folly to be wise." How much the better or happier are we they say, for our painfully acquired knowledge of "bacilli" and "bacteria" and "germs," what need to be told that disease and death may lurk in the air we breathe, in our food and drink, in the very dust beneatl our feet; to these we would reply-much every way, hecause disease is preventable, and death may be postponed, and even a little knowledge is not a dangerous thing if that little is accurately learnt and cam be imparted intelligently to another less well informed.

It is not intended that in these matters women should trench upon the province of men, but the drainage, rentilation, and lighting of our houses, the purity of water, milk, meat, \&c., the proper preparation and cooking of food, cleanliness in the person and house, the care of children and nursing of the sick, the management of infectious diseases and removal of all impurities that may gender disease, these and kindred subjects should come under the teaching of domestic economy, and erery girl shonld have such a thorough training and eximinination in them. as will enable her to leave school equipped with real practical knowledge that cannot fail to be of the greatest help to her in after life.

This training should be, $\mathrm{I}$ consider, available for rich and poor alike, for if needful for wur own children, how much more desirable is it for the children of the poor who have to tight the battle of life against such terrible odds in our sreat cities and in the rural districts of our land. In the scheme then of technical education, side by side with classes for cookery, laundry work, sewing and the like, it seems to me that some teiching of what I may call the first rudinnents of sanitation should find a place, and children should be taught, as far as possible by practical demonstration, the groundwork of real house-wifery; a few simple lessons on the structure of the human frame, illustrated by diagrams, might be used to explain what are the requirements of these bodies of ours in order to maintain them in health; and the principles of rentilation, the why and 
wherefore of good air rersus bal in oul homes might be explained. Such a scheme has been adopted in London in comnection with the Board Sichools, and is found to work well; some of the questions set for the "house-wifery" examination of these classes in July last, have come under my notice, and while simple and easy of comprehension they are all framed with a view to their utility. That such classes lave not been formed elsewhere in connection with the board schools of our provincial towns may possibly be due to the somewhat expensive machinery required, for in order that the children may be effectually taught and trained, it las been found necessary to fit up and furnish two or three rooms, a miniature " house" in fact, where all that pertains to the requirements of kitchen, bellroom, sitting room, \&c., are provided, and in which there is daily manual practice in actual housework conducted on sanitary principles, The girls are instructed in the kitchen how to guard against waste in the preparation of fool, and how to dispose of the refuse that is so of ten allowed to accumulate in the dwellings of the poor until it becomes a source of danger and infection; in the bedroom the best method of safe and effectual ventilation without draughts, and how to keep it wholesome and clean ; and in the parlour how to combine beaty and comfort with strict conomy, and to make it cheerful and bright and pleasant upon such small means as a working man has at command. This is what has been and what ought to be done for the children, and side by side with the desire to train the younger greneration to a useful knowledge of the laws of hygriene, there comes naturally the wish to improve the habits and condition of the women, of the wives and mothers and sisters of the working men, in whose hands lies so largely the power to make or mar the comfort of the home.

For some time there has been a morement stirring in this direction, ladies trained at Health Lecturers have in many districts given short useful addresses at mothers' meetings, plain tallis on household topies, in which they lave sought to gain the confidence of the women, to sympathise with, and counsel them in their household difficulties and family cares, and while plainly pointing out the evils resulting from dirty slovenly habits, and want of order, enconraging them in every desire for improrement, proving to them by clear and practical demonstration that life or death may lie concealed even in a grain of dust, or a drop of water.

To be thoroughly helpful, however, these lectures should, I think, be followed up by home visitation where practicable, when by the exercise of tact and kindly feeling many useful hints may be offered, without giving offence, on the sanitary 
condition of the person and the house, and the management of health in both adults and children. This plan of sending health missionaries into the homes of the poor has been tried with much success among women of the labouring class in one of our midland counties. I trust it may not be long before Liverpool also has its health missionaries, who armed with knowledge and experience of domestic sanitation, may be found ready to help those who are willing but unable alone to help themselves. May I in conclusion be allowed to quote the words used by Dr. Edward Seaton, Professor of Hygiene at St. Thomas's Hospital, London, in his report of the British Committee, recently submitted at the International Hygienic Conference at Buda Pest. He urges that the scope of hygiene, which in England has far too narrow a signification, shall be extended so as to include sanitary or preventive medicine. Otherwise, he contends, "it will be impossible successfully to combat diphtheria, infuenza, and other diseases which can only be properly termed preventable when the public understand the necessity for the systematic encouragement of scientific observations and research bearing on the public health." 